\title{
The Future of Universities: Is Digitalization the Priority? (Expert View)
}

\author{
Valerii S. Efimov and Alla V. Lapteva* \\ Siberian Federal University \\ 79 Svobodny, Krasnoyarsk, 660041, Russia
}

Received 06.09.2018, received in revised form 03.12.2018, accepted 11.12.2018

The ongoing digital revolution is changing the economic and social environment where universities exist as well as universities themselves. The aim of the research presented is to throw light upon some aspects of "digitization" of universities using expert knowledge. A largescale survey of experts (1481 experts from 65 Russian universities) was applied as a method of research. The task of the survey is to identify what digitalization ranks among other largescale changes and problems topical for the modern university; how "digital challenge" should influence the priorities of university development management; to what extent the real priorities of the management of Russian universities reflect the significance of the "digital challenge".

The survey shows that the expert community considers "the total digitalization" to be the leading trend that changes economy and society nowadays. The main challenge that higher education will face in the period until 2035 will be "digitalization", which is the need for a large-scale use of digital technology in education and university management. At the same time, the experts believe that "critical situations" for higher education in Russia in the future may arise as a result of the possible "degradation of secondary education" and the country's development according to the "raw materials" scenario. Accelerated technological development of the economy and society based on digital technology will not be a trigger of critical situations for higher education in the future. In the system of development priorities, investment in digital infrastructure should rank high, and we can expect "rapid effects" of this investment.

However, according to experts, "PR and promotion of the university" and "cooperation with the Ministry of Education and Science and federal agencies" rank the first and the second respectively among the actual priorities for the development of universities; investment in digital infrastructure is in the third position. Thus certain "deformation" in the management of university development takes place, which means that the main trend of changes and the challenge for universities is "digitalization", but in the management practice it ranks only third among the priorities. The actual priority of the following areas of investment is even lower: investment in motivation of teachers and students ("investment in dynamic"); international cooperation; cooperation with business; development of educational technology; attraction of "new students" and "new personnel"; exploratory research; support for scientific schools.

(c) Siberian Federal University. All rights reserved

* Corresponding author E-mail address: efimov.val@gmail.com; avlapteva@yandex.ru

This work is licensed under a Creative Commons Attribution-NonCommercial 4.0 International License (CC BY-NC 4.0). 
Keywords: universities, higher education reforms, digital revolution, digital technology, development priorities, investment in development.

The study was supported by the Krasnoyarsk Regional Fund for Support of Research and Research-Technical Activities in the framework of the project "Prospects for the formation of a digital economy in Krasnoyarsk Krai: priority areas, technology, personnel."

Research area: economics.

Citation: Efimov, V.S., Lapteva, A.V. (2018). The future of universities: is digitalization the priority? (Expert view). J. Sib. Fed. Univ. Humanit. soc. sci., 11(12), 1925-1946. DOI: $10.17516 / 1997-1370-0367$.

\section{Introduction. Context and objectives of the study}

In recent decades, digital technologies have had an increasingly significant impact on almost all areas of activity and human life in both developed and developing countries. An increasing share of value in the economy is created by the use of digital technologies, which suggests the emergence of a "digital economy" (The World Bank, 2016; Ustiuzhanina et al., 2017). Digital technologies are used both in work and leisure activities; a generation of people who cannot imagine their life without electronic "gadgets" such as mobile phones, laptops, tablets, etc. grows up. One can speak of a "digital person", for whom digital technologies have become an integral part of both activity and the fabric of everyday life (Fig. 1).

Digital technologies have existed for decades and continue to develop so intensively that even the contours of them (as a certain "class" of technologies) and the opportunities created by them have not yet been comprehended and outlined even approximately. "At the start" the technologies for converting analog signals to digital, technologies for transmitting and processing digital signals were created. On this basis, computers and equipment for digitizing images, sounds, etc. and digital communication channels were designed. Further, on the basis of microprocessors personal computers and many other devices with the most different functions were created; digital communication expanded to the extent of the global Internet. Currently, digital technologies of the next level that is the level of virtual and augmented reality, artificial intelligence, robotics, the Internet of things, "smart systems", etc. are being developed. In the future, the creation of neural interfaces and deep integration of the computer and the human brain are possible. When digital technologies are combined with financial, social, humanitarian and other technologies, whole areas of "new reality" appear, including "digital" education.

Thus, the digital revolution changes the reality surrounding universities and changes universities themselves. Its impact on humanity will be no less significant 


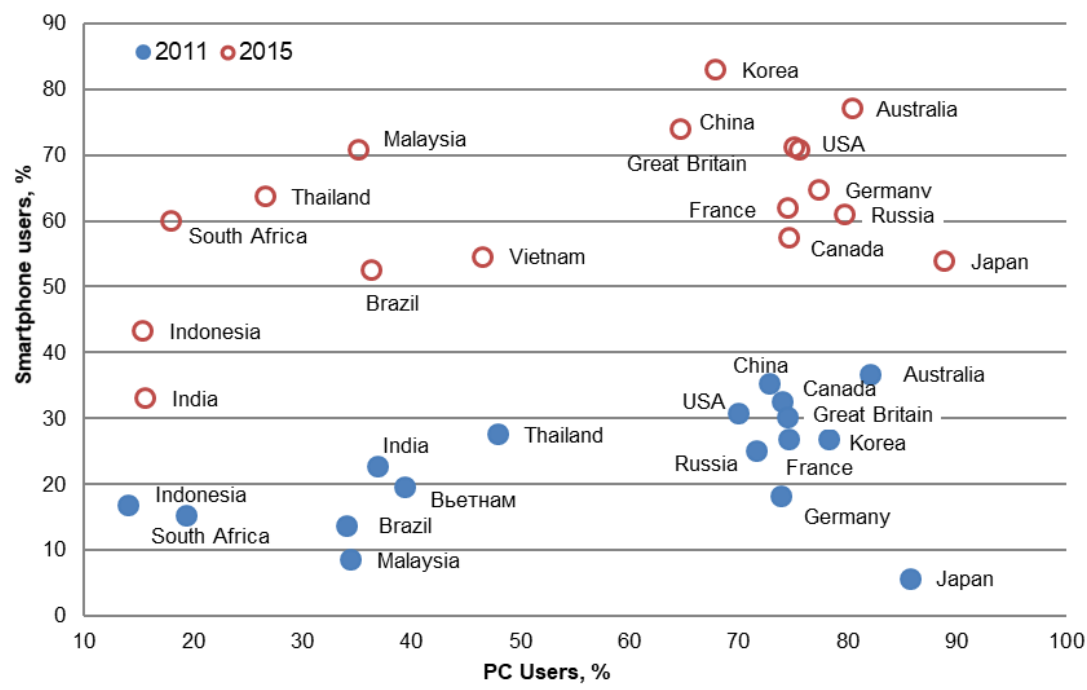

Fig. 1. Dynamics of the number of PC and smartphone users in developed and developing countries $(2011,2015), \%$ of adult population (Akhtamov et al., 2017: 29)

than the impact (civilizational consequences) of the printed revolution, which made it possible to replicate and spread knowledge and ideas in the form of a "printed word".

The connection of changes in universities with total "digitalization" of the economy and society and the university itself has become a generally accepted idea. The various components of "digitalization" of universities are discussed: 1) online education, 2) electronic educational resources, 3) administration using digital technologies (electronic document management, etc.), 4) training using simulators, augmented reality, virtual reality, 5) the formation of competencies required in the digital world (Semenova et al., 2018; Johnson et al., 2016; OECD, 2016; Onlain-obuchenie..., 2015; Neborskii, 2015; Siemens et al., 2015; Trends in Higher Education..., 2014; Picciano, 2012).

When thinking about a new situation that is universities in the digital world, it is important to understand:

- what "digitalization" ranks among other changes unfolding globally ("global trends");

- whether the "digitalization" of the economy, society, man becomes a challenge for universities, what this challenge ranks among others that are relevant for a modern university;

- what "digital challenge" means for managing the development of a university, for investing in development, how it can and should affect the system of development priorities; 
- the extent to which real priorities in the management of the development of Russian universities reflect the significance of the "digital challenge".

These issues require a whole range of research. This article presents the results of a survey of experts working in the field of higher education and science concerning some aspects of the "digital perspective" of universities.

\section{Research Method}

A large-scale survey of experts was used as a research method, in which 1481 experts, who were employees of federal, national research and other universities of the Russian Federation (65 universities), took part. The survey period is October 2017. In territorial terms, the pool of the experts represents all regions of Russia from the European part to Siberia and the Far East. The overwhelming majority of the experts are scientists and educators, their number is 1336 . The experts are represented by four age groups:

- up to 35 years $-24.2 \%$ of respondents;

- 36-50 years old - 36.1\% of respondents;

- 51-65 years old - 23.6\% of respondents;

- over 65 years old - 16.1\% of respondents.

$47 \%$ of men and $53 \%$ of women were the experts.

As a survey toolkit, a questionnaire that included four sets of questions was used. 1.The future of universities - global context.

2. The future of higher education in Russia: scenarios, mission, functions.

3. Development of universities: development models, investment in development.

4. Public policy measures.

In total, the questionnaire contained 12 questions; the wording of questions and response options were compiled based on the analysis of: 1) scientific literature on the problems of higher education development in Russia and in the world, 2) the materials of expert interviews and expert sessions, 3) the results of the expert survey conducted by the authors in 2011 presented in the report (Efimov et al., 2012b).

This article analyzes the answers of experts to 6 questions that affect various aspects of the "digital perspective" of universities. As a rule, the experts were asked to assess the probability of the manifestation and degree of influence of various processes in the economy and society or the consequences of these processes such as "challenges", "critical situations" on universities.

As a result of preprocessing, part of the questionnaires were rejected, particularly partially completed questionnaires and expert questionnaires, using mostly the same 
ratings (that is, non-informative to distinguish between different answers), were excluded. The base used to analyze the survey results was 959 questionnaires.

A methodology for analyzing the results is presented in (Efimov et al., 2012a: 29-30; Efimov et al., 2012b: 28-29). According to this methodology, the average score was calculated for each answer option, as well as a special index characterizing the deviation of the average score by the answer option from the average score for all the answer options for this question, taking into account the degree of consolidation of experts. The formula for calculating the index for the $\mathrm{i}$ answer is the following:

$$
\mathrm{Wi}=(\mathrm{Xi}-\mathrm{Xav}) / \mathrm{STANDART} \text { DEVIATION }(\mathrm{Xi})
$$

where $\mathrm{Xi}$ is the average value of the estimates for the $\mathrm{i}$ answer option; Xav is the average value of the estimates for all the answers to this question; STDEV (Xi) is the standard deviation of estimates for the $\mathrm{i}$ answer option. The standard deviation is calculated as the root mean square.

The index calculated in this way reflects, on the one hand, the deviation of the average assessment of a certain answer option by the experts from the average of the estimates for all the answer options (within the limits of one question). The average value of the estimates for all answer options in this case corresponds to the zero value of the index and plays the role of a point of reference. On the other hand, due to the division by standard deviation, the index takes into account the consolidation (consistency or variation) of expert assessments for this answer: the higher the degree of consolidation of expert evaluations is, the smaller the standard deviation is and, therefore, the greater the absolute value of the calculated index is. In fact, the index used in this method is the deviation from the average, measured in standard deviations.

The results of processing the survey data are presented below in the form of "maps" with two axes of coordinates - the abscissa axis of one index (for example, probability), the ordinate axis reflects the values of the other index (for example, significance). The answer options are plotted on the "map" in the form of markers, their position relative to the coordinate axes reflects the position of the experts on a particular issue.

\section{Results of the study}

The survey results show that the expert community clearly identifies "digitalization" as a key direction of changes occurring in the world and in the field of education in 
particular, as a significant challenge for universities and as a priority for the development policy of higher education.

\section{1. "Digitalization" is the most significant global trend}

The experts were asked to assess the probability of manifestation (in the time horizon until 2035) and the degree of influence on universities (and higher education in general) of a number of "global trends" in the future (economic, social, demographic, cultural processes unfolding globally and affecting almost all countries and regions):

1. Total digitalization: expanding the use of digital (computational, multimedia, information and communication, etc.) technologies in all spheres of human life and activity - in production, social and cultural spheres, in public life, in individual human life.

2. Globalization: globalization of markets, including the markets of knowledge, technology, innovation, education, R\&D, consulting; expanding the network partnership of universities (including in the virtual space); internationalization of education and research.

3. Increased competition: increased competition, including in the field of R\&D, in the production of innovations, education between universities of developed and developing countries, between universities and other cognitive institutions (research centers, innovation companies, digital media, etc.), the redistribution of markets in favor of universities that are world leaders.

4. The growth of mobility and the expansion of human capabilities: the growth of a person's subjectivity and the possibilities for them to choose the places, ways and content of their life, activities and education; a significant expansion of a person's ability to determine his / her identity, to build an individual educational trajectory (using the resources of various universities, online platforms, etc.).

5. Mass education: an increase in the proportion of students receiving a university education in all age groups (youth, adults, people of the "third age").

6. Cognitive revolution: the growth of the scale and importance of intellectual and creative activity; the formation of new types of collective and hybrid (humancomputer) intelligence, new ways and formats of production and reproduction of knowledge; the change in human cognitive abilities; the massive introduction of "smart systems" based on Big Data and artificial intelligence, process automation ("smart manufacturing", "smart networks", "smart cities", etc.).

The results of the analysis of the expert responses are presented in Fig. 2 in the form of a "map", the horizontal axis reflects the indices of probability of manifestation 


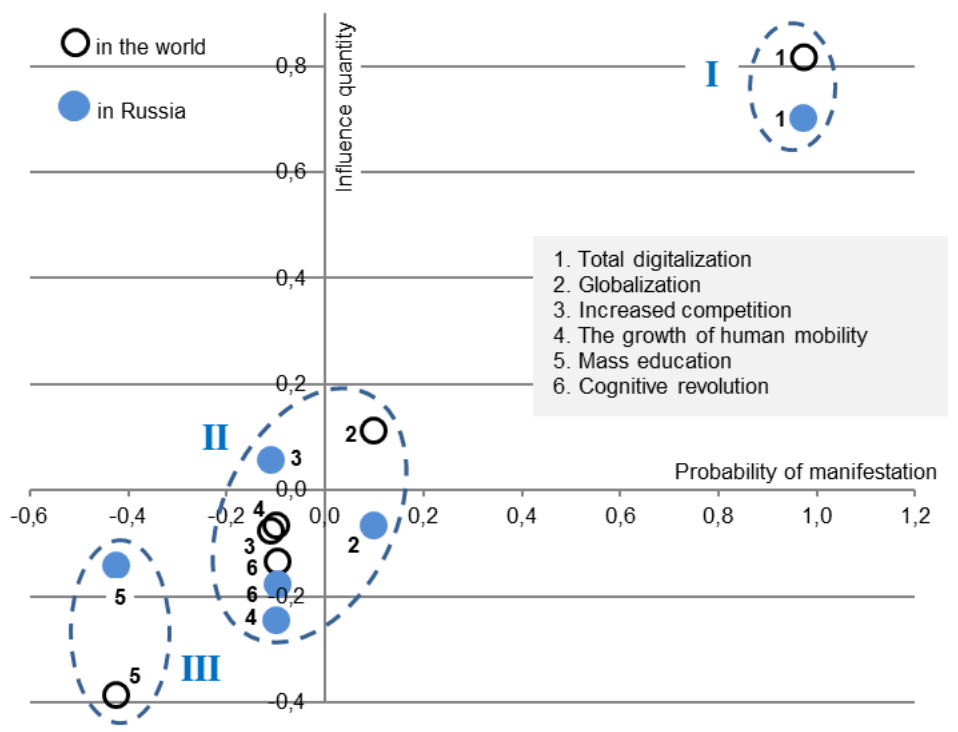

Fig. 2. The probability of manifestation and the degree of influence of various large-scale changes ("global trends") on higher education in the world and in Russia - expert vision

of various trends calculated on the basis of the expert estimates, the vertical axis shows the indexes of the influence of these trends.

From the point of view of the experts, the trend of "total digitalization" stands out sharply among other significant processes in terms of the probability of manifestation and the degree of influence - both are rated as very high (Group 1 in Fig. 2). At the same time, the degree of influence of "digitalization" on universities in the world and in Russia is equally assessed as extremely high.

Other trends are assessed as average probable and moderately significant - Group 2 in Fig. 2. The process of "mass education" is assessed as the least possible and having a weak effect on universities in Russia and especially in the world - Group 3 in Fig. 2. We believe that the experts view the massification of higher education as an accomplished fact as the proportion of those receiving higher education is already large, and some additional effects and aftereffects of massification are not expected.

Regarding the estimates of the probability of manifestation and the degree of influence of various processes in the world and in Russia, we can note the following. The probability of global trends in the world as a whole and in Russia is estimated almost the same - this may mean that Russia is viewed by the experts as deeply integrated into the outside world, experiencing the same economic, technological, social and cultural changes along with most other countries. However, according to the experts, the degree of impact of these changes on universities in the world and in Russia is somewhat 
different: in Russia, higher education is more exposed to the effects of competition and mass education, but less exposed to the effects of globalization, the growth of mobility and the expansion of human capabilities.

In general, we shall conclude that "total digitalization" is the main trend, which with a high probability will be manifested in the time horizon until 2035 and will have the strongest influence (in comparison with other processes) on the reality of higher education.

\section{2. "Digitalization" - a significant challenge for higher education}

Another opportunity to assess the changes is to discuss them in terms of the "challenges" they create for higher education: a challenge means a special "urgency" of the emerging new situation, the inability to continue to act on the basis of previous approaches and methods, the need to develop universities. The experts were asked to answer the question - "What challenges will universities face if many of the trends under discussion truly unfold and transform the life of society and the individual?" Rate the probability of manifestation of these challenges in the time horizon up to 2035 and the degree of their influence on universities in the future on a 5-point scale." The following answer options (challenges) are proposed for evaluation:

1) mass education: the enrollment of poorly trained students and "unusual" students (adults, migrants, etc.) by universities; the need to develop new technologies of education and learning motivation;

2) competition with global universities and consortia of leading world universities for talented students, prospective researchers and teachers;

3) internationalization: the need to ensure teaching in English, international accreditation of programs, adherence to the norms of tolerance in a multicultural environment, to learn the practice of cooperation with people from other cultures and lifestyles;

4) digitalization: the need for a large-scale use of new digital technologies in education and university management (Big Data, intelligent robots, a comprehensive digital environment of the university, etc.);

5) generation gap: the widening of the gap between the new generations of students and the teaching staff (different value systems, worldviews, lifestyles, ways of teaching / learning);

6) the effects of the cognitive revolution: the emergence of new ways of producing and reproducing knowledge, types of thinking and communication; the formation of 


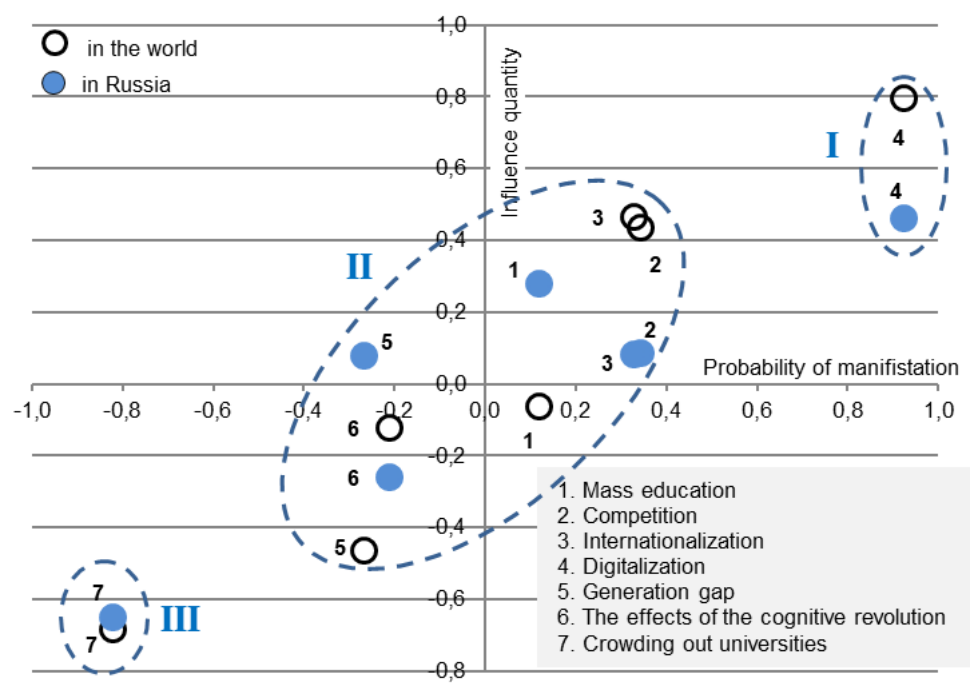

Fig. 3. The probability of manifestation and the degree of influence of various challenges on universities in the world and in Russia - expert vision

new types of collective and hybrid intelligences; profound changes in human cognitive abilities;

7) crowding out universities to the periphery of cognitive processes: the production of knowledge, innovation, "development events" of a person, the formation of "collective intellects", the reproduction of knowledge will take place outside universities - in innovative companies, think tanks, the intellectual digital environment, etc.

According to the experts, universities are most likely to face the challenge of digitalization, which is the need for a large-scale use of digital technology. This challenge will have the greatest impact on universities both in the world and in Russia; at the same time, the impact assessment for Russia is somewhat less: the value of the influence index does not exceed +0.5 (Group 1 in Fig. 3).

"Crowding out universities to the periphery of cognitive processes" is the least likely; besides, the experts saw the possible impact of this challenge on universities both in Russia and in the world as very low (Group 3 in Fig. 3).

The remaining challenges discussed can be attributed to the group of average probable, with an average degree of expected impact on universities - Group 2 in Fig. 3. At the same time, the probability and impact of the following challenges are assessed comparatively higher: 1) competition (with global universities and consortia), 2) internationalization (teaching in English, international accreditation of programs, etc.). The effects of the cognitive revolution, the generation gap are evaluated comparatively lower. 
According to the experts, the probability of the situations of "challenges" for the world and for Russia differs slightly. The degree of influence of the "challenges" in the world as a whole and in Russia will differ: in Russia, the problems associated with digitalization, internationalization of universities and their competition will be less acute. Apparently, this is due to some delay in Russian universities in terms of their involvement in the relevant processes and the "catching up" nature of development (through technology transfer, formats of activities, organizational decisions, etc.). At the same time, the challenges associated with mass education and generation gap are relatively more significant for Russian universities.

In general, we shall conclude that "digitalization" is the main thing among the discussed challenges. This challenge combines a high probability of manifestation and a high degree of influence on universities.

\subsection{Critical situations possible in the future of higher education}

In addition ${ }^{1}$, the experts considered possible (in the time horizon until 2035) critical situations for higher education in Russia. It was proposed to assess the probability of these critical situations and their significance (possible impact) for the future of higher education.

Critical situation 1: Stagnation of higher education and science in the context of the realization of the "raw material" scenario: low demand for research, innovation, quality education; brain drain, etc.

Critical situation 2: Higher school loses competition with corporate research centers, corporate universities, foreign universities in the field of development, innovation and training. High school loses status and access to resources.

Critical situation 3: The composition of "consumers" of higher education changes, i.e. the proportion of adult, international students grows. Programs, educational technologies and higher education personnel become out-of-date. It loses competition with foreign universities, online platforms, etc.

Critical situation 4: Modernization of education and science is limited to megacities (Moscow, St. Petersburg, etc.). General and higher education in the Russian regions degrades.

In the structure of the questionnaire before this question, the experts considered various socio-economic scenarios of the future of Russia, which set the context for assessing the probability and significance of critical situations. In this article, due to its limited scope, we do not provide survey data regarding scenarios. 
Critical situation 5: The quality of schooling decreases. The higher school is forced to "reach out" weak applicants to the "normal" level - this blocks the educational process. High-quality education is preserved in elite universities, leading a strict selection of applicants.

Critical situation 6: Intelligence enhancement technology (computer-brain interfaces, visualization of objects of thought, software for collective problem solving, etc.) is massively introduced. Educational standards, programs, technologies and personnel of higher education are completely outdated. Higher school loses the role of the main educational institution.

Critical situation 7: Technological development is sharply accelerated - robotics, expert systems, "smart systems", etc. are introduced, the volume and structure of employment of the population, a set of professions and qualifications change. Educational standards, programs, and educational technologies at universities are completely outdated.

The indices of probability and significance of critical situations calculated on the basis of expert estimates are presented in Fig. 4. Situation 5 (the critically low quality of applicants, which blocks the educational process and leads to a drop in the quality of higher education with the exception of elite universities) stands out sharply among

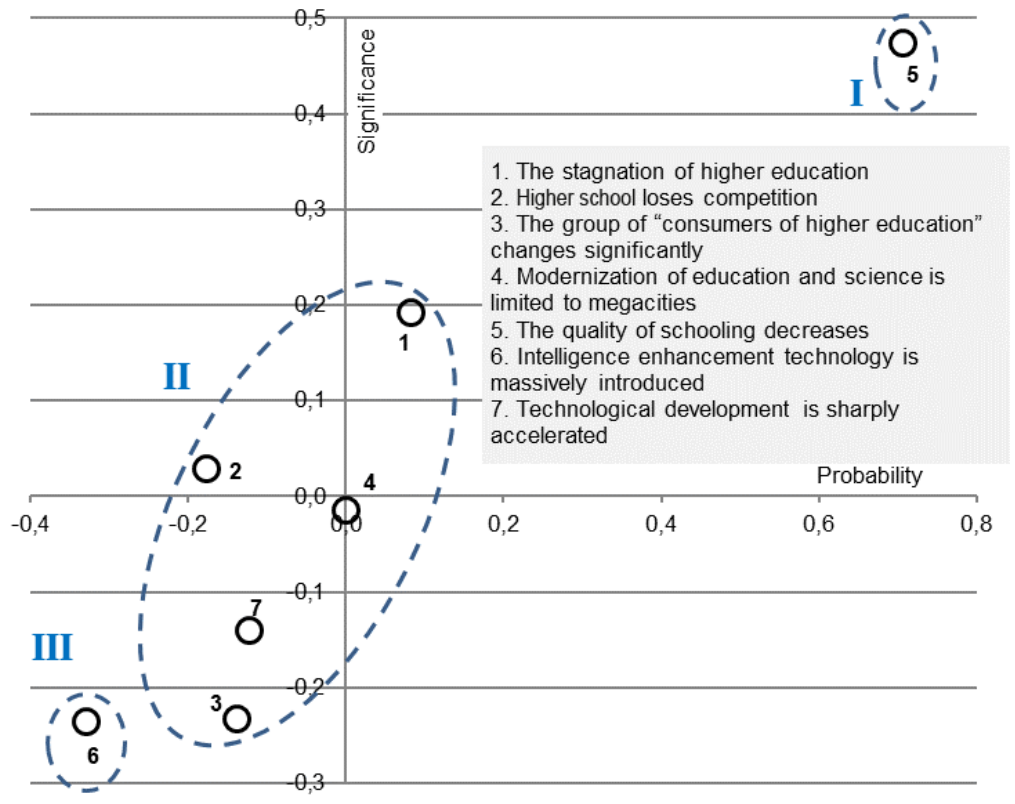

Fig. 4. The probability of occurrence and the degree of influence on universities of possible critical situations - expert vision 
critical situations due to the high probability of occurrence and significance for the future of higher education.

The critical situation with the smallest indexes of probability and significance is situation 6 (the massive use of digital intelligence enhancement technologies).

The rest critical situations can be classified as average probable and moderate in terms of the degree of potential influence (Group 2 in Fig. 4). Among them, situation 1 , which is the stagnation of higher education and science in the context of the "raw material" scenario of economic development, stands out relatively.

Situations 6 and 7 related to the prospects of digital technologies are interesting in the context of the topic of this article. The experts believe the probability that digital technologies in various manifestations (intelligence enhancement technologies or robotics and "smart systems") will create a critical situation for universities, namely will lead to obsolescence of educational standards, programs, technologies, and higher education personnel, is rather low. Accordingly, the significance of these critical situations is considered low.

We can conclude that, according to the experts, digital technologies are not among the most significant sources of risk for higher education, up to the occurrence of critical situations. The possible degradation of school education and the "raw material" socioeconomic development scenario are seen as the sources of critical situations in the future.

\section{4. "Digitalization" in the system of university development priorities}

Above it was shown that "digitalization" (mastering digital technologies, corresponding formats of activities and communications, building a holistic "digital reality") of a university is considered by the experts as the mainstream of its transformation in the coming decades. The "digitalization" of reality surrounding the university is the most significant trend that will set the main challenges for higher education. If so, then the "digitalization" of the university should have a special place in its strategy, in the system of development priorities. At the same time, it is important to distinguish priorities as verbal declarations, reflecting the current state of the development agenda, from real priorities - the latter are expressed through realized "investments in development". We understand the entire set of investments of resources in certain areas of activity as investments in development, which are expenditures of funds, time of managers and employees, provision of infrastructure, place in the information space, status and image support. 
In the questionnaire for the survey of the experts, two questions were devoted to investing in the development of universities:

- Imagine that you are the head of a leading university. What would you invest in to ensure the development of the university? Rate on a 5-point scale: 1) the priority (significance) of the following areas of investment, and 2) the possibility of achieving "quick effects" (in 3-5 years).

- What is invested at your university now? Rate (from 1 to 5 points) the priority of investments made at your university in the recent 3-5 years on a 5-point scale.

In the first case, the expert's answers reflected his idea of the proper - what the priority directions of investments in the context of development objectives should be and what investments can be expected to have a quick return. In the second case, they reflected the idea of the real - what the actual priorities of the investments made in the university in which the expert works (or the situation which he knows well) are.

The list of areas of investment in development included the following items.

- Scientific schools as units that integrate the achievements of scientific attainment, the reproduction of scientific personnel, the formation of scientific reputation.

- Exploratory, breakthrough research as the basis for the future leadership of the university in certain areas of science and technology.

- New staff members - attracting leading scientists, international professors, practitioners with unique experience, talented young scientists and teachers to the university.

- Educational technologies of the new generation - creating packages of online courses, increasing mobility and individuality of education, new organization of the educational process (offline and online); simulators, case study, virtual laboratories, teacher robots, business games, simulation activity games, etc.; technology motivation and support for students.

- New students - attracting talented students and expanding the circle of students from different regions / countries and older age groups.

- Modern scientific and laboratory equipment, including unique instruments, installations, instrument complexes.

- Digital infrastructure - computer networks, computing power, software, electronic university system, digital educational environment, etc.

- Innovation infrastructure - university technopark, business incubators, prototyping centers, patent support and protection of intellectual property, the possibility of creating start-ups and small innovative enterprises. 
- University campus - academic buildings, research laboratories, dormitories, sports facilities, hotels, congress hall, medical center, libraries, etc.

- International cooperation - entry into international research and educational networks, joint research and development, partnership educational programs.

- Cooperation with business - negotiation and presentation platforms, specialized academic departments in enterprises, the formation of "backlogs" of R\&D, attractive for potential partners.

- Cooperation with the Ministry of Education and Science and federal agencies direct contacts with representatives of the Ministry of Education and Science and its departments, lobbying for the interests of the university; carrying out research and development on the order of the Ministry of Education and Science, participation in the development of federal programs of higher education.

- Modernization of the management system - the introduction of new approaches and promising management models; introduction of digital technologies in management; update and rotation of managerial personnel.

- The system of motivation and involvement of teachers, staff and students in development processes - the creation and support of communication platforms, the system of internal grants, stimulating wages.

- $P R$ and university promotion - special design and public representation of university achievements; active interaction with key stakeholders (government, business, community, etc.); active presence in the public world, federal and regional information field.

The results of the analysis of answers to the question about the importance and priority of areas of investment in the development of the university and the possibility of quick return are presented in Fig. 5.

The experts believe that the system of motivation and involvement of teachers, staff and students in development processes is a high priority for investment in development, which at the same time can have quick effects. It can be said, this is "investment in activity" (Group I in Fig. 5).

Further, high priority areas with average indices of the possibility to obtain quick effects are highlighted: 1) investment in modern scientific and laboratory equipment, 2) investment in digital infrastructure (Group 2 in Fig. 5).

Most of the areas of investment in development can be combined into an "average" group, for which average values of priority indices and the possibility of obtaining quick effects are received (in Fig. 5, Group 3 near the origin). 


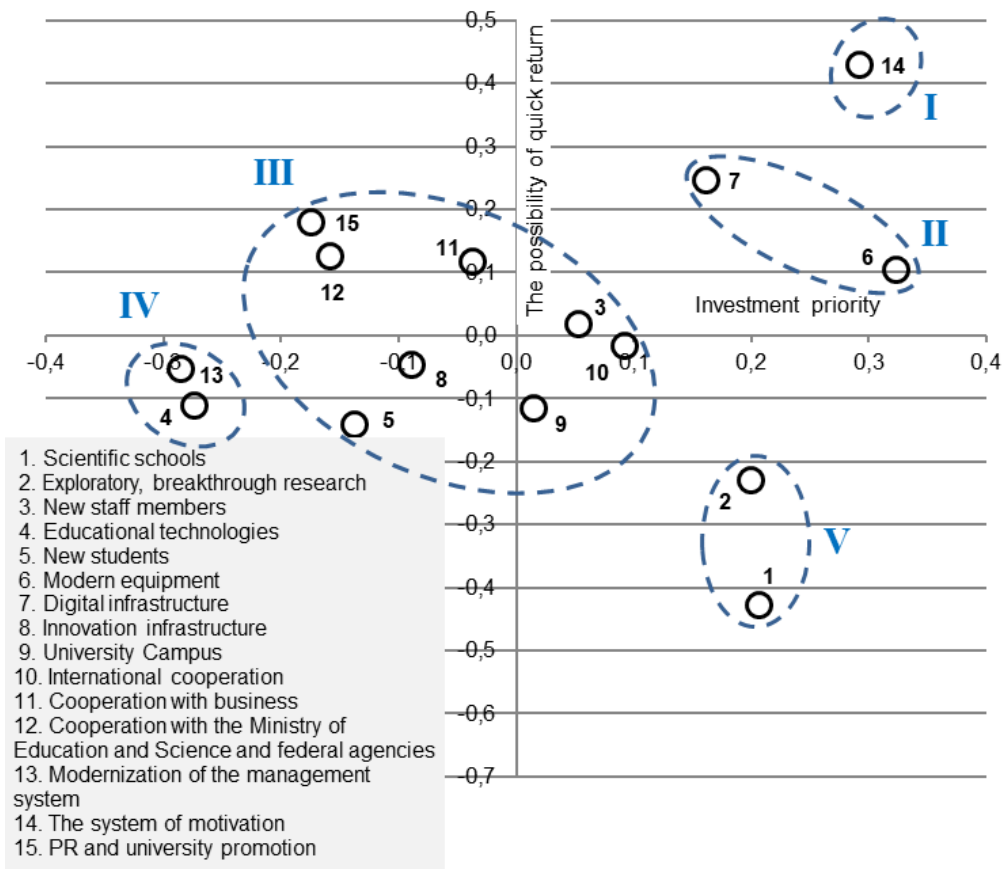

Fig. 5. The priority of various areas of investment in the development of the university and the possibility of obtaining quick effects - expert vision of the proper

According to the experts, the relatively least priority areas are: 1) educational technologies, 2) management system modernization (Group 4 in Fig. 5).

Two areas of investment in scientific schools and in exploratory research (Group 5 in Fig. 5) are rated as high priority, and they do not promise quick returns: "growing" scientific schools and a scientific search in potentially "breakthrough" areas take time.

Thus, from the point of view of the experts, investment in digital infrastructure (computer networks, computing power, software, electronic university system, digital educational environment) is one of the priority areas of investment, and one can expect "quick effects" that is the quick return of these investment.

Fig. 6 presents the results of the analysis of the answers to the question of what the actual priorities for investment in the development of universities are. On this "map", the abscissa axis reflects the values of the investment priority indices (the proper), the vertical axis reflects the value of the actual priority indices, which clearly shows the "ratio of the proper and the actual" in the practice of university development (from the point of view of experts).

Areas of investment in development can be divided into six groups.

Group 1 - a high priority is combined with a high actual priority; this group includes investment in the university's digital infrastructure. 


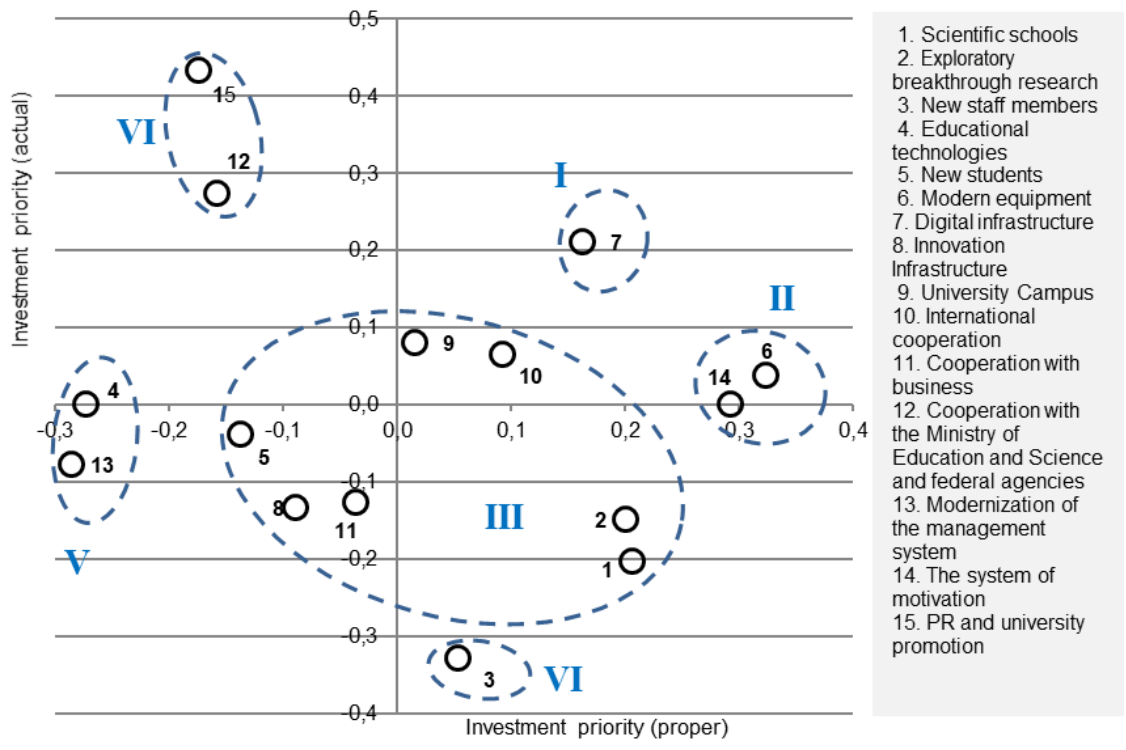

Fig. 6. The proper and the actual priority of various areas of investment in the development of the university - expert vision

Group 2 - a high priority is combined with an average level of an actual priority (2 in Fig. 6). We can say that this investment is somewhat undervalued in actual management practice. This group includes investment in modern scientific and laboratory equipment and in the system of motivation.

Group 3 - an average level of a proper priority is combined with an average level of an actual priority (3 in Fig. 6): university campus, international cooperation, cooperation with business, "new students", innovation infrastructure, research and scientific schools.

Group 4 - an average level of a proper priority is combined with the lowest actual priority (4 in Fig. 6): this "new staff members" direction means attracting leading scientists, international professors, practitioners with unique experience, talented young scientists and teachers to the university.

Group 5 - a low level of a proper priority is combined with an average level of an actual priority (5 in Fig. 6): investment in educational technologies and modernization of the management system.

Group 6 - a relatively low level of a proper priority is combined with a high level of actual priority (6 in Fig. 6): cooperation with the Ministry of Education and Science and federal agencies, PR and university promotion. We can say that these two directions are overestimated in the practice of managing the development of universities - they "take" more resources than their position on the scale of the proper priorities supposes. 
On the whole, we can conclude that both the experts' views on the proper priorities of investment in development, and their assessment of the actual priority of various areas of investment reflect the importance and priority of the "digitalization" of the university. However, it should be noted that among the actual priorities of the development of universities in the first place is "PR and university promotion", while the second place is taken by "cooperation with the Ministry of Education and Science and federal agencies". These estimates seem to reflect the fact that in the current situation, universities receive funds beyond the current funding (which, in fact, can be invested in development) mainly through projects (such as "5-100") and development programs (of federal universities, NRU, etc.).

Under these conditions, university management is forced to focus on two tasks: 1) to maintain close contacts with the Ministry of Education and Science, "invest" the time and attention of their management in achieving the status of a participant in any projects and programs, and retain this status, 2) "to promote" university achievements, to be actively present in the information field, which also allows you to retain university status and attract financial and other resources. These two tasks "push aside" all the others, such as the task of digitalization (to a lesser extent) and the task of investing in activity, in cooperation (international and with business), in educational technologies, "new students" (to a greater extent), and especially in exploratory research and scientific schools, in new staff members.

\section{5. "Digitalization" in the system of higher education reforms in Russia}

The experts were asked to evaluate public policy measures implemented in recent years and now, elements of higher education reform in two ways: 1) efficiency achieved so far, 2) prospects for future measures aimed at reforms. The following reform areas were estimated:

- accession of Russian universities to the "Bologna system", transition from the training of specialists to a two-step higher education (Bachelor's and Master's degree programs);

- transition to enrollment of applicants to universities based on the results of the Unified State Exam and academic competitions;

- differentiation of universities, allocation and support of leading universities (federal universities, national research universities, participants of the "5-100" program);

- allocation of mega-grants to attract leading international professors to Russian universities; 


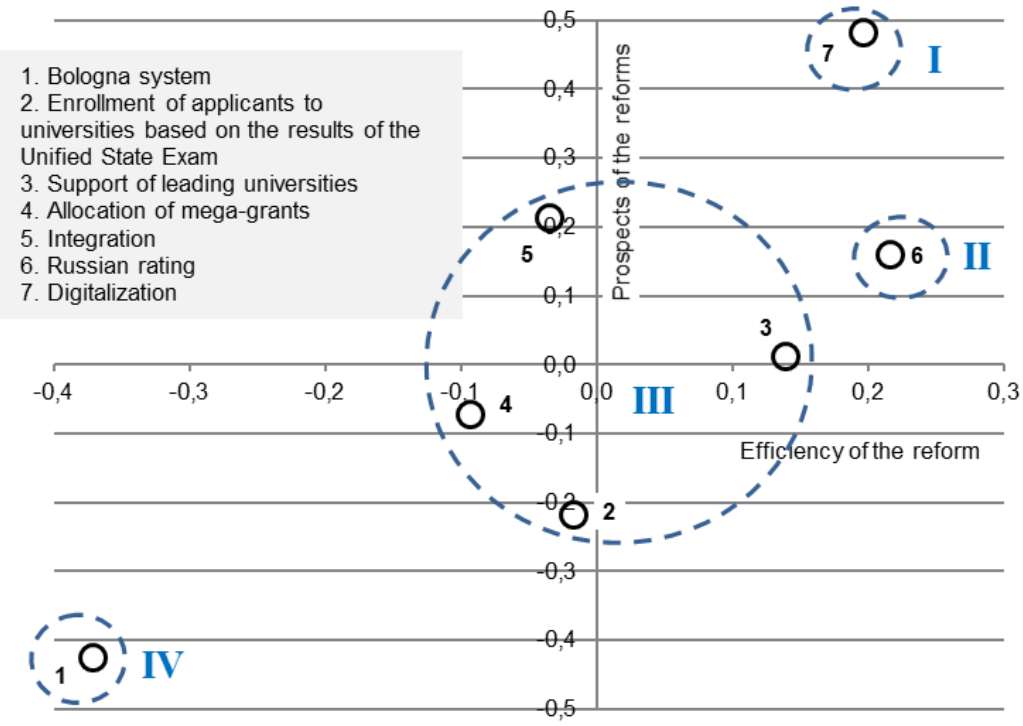

Fig. 7. Efficiency and prospects of various areas of higher education reform - expert vision

- measures to integrate Russian universities into the international educational and research space (international accreditation of educational programs, grants for joint research with foreign partners, etc.);

- creation of a Russian university ranking, taking into account the particularities of the country;

- digitalization of the educational process in universities (creation of a system of online courses, the use of electronic platforms, accepting the fact of taking online courses at other universities and at "external" educational platforms - Coursera, etc.).

The survey results (calculated indices of efficiency and prospects of reforms) are presented in Fig. 7.

Among the areas under discussion, it is "digitalization of the educational process" that stands out by the fact that it combines the already manifested efficiency with high prospects in the future (Group 1 in Fig. 7).

The creation of a Russian university ranking combines a relatively high efficiency achieved and an average level of prospects (Group 2 in Fig. 7).

Most of the areas of the reform are grouped on the "map" near the origin, which means they are assessed as moderately effective and promising (Group 3 in Fig. 7). These are measures for integration into the international educational and research space, support for leading universities, allocation of mega-grants to attract leading foreign scholars, enrollment of applicants to universities based on the results of the Unified State Exam and academic competitions. 
Accession to the Bologna system (transition to a two-stage higher education) is estimated as the relatively least effective and promising direction of reforms (Group 4 in Fig. 7).

Thus, "digitalization" (as applied to the educational process) is considered by the experts as the leading direction of the ongoing and possible future reforms of higher education in Russia.

\section{Conclusions}

The article discusses the results of a large-scale expert survey, affecting various aspects of the future of higher education in Russia and the reforms happening here. When analyzing the survey results, we highlight one aspect of the ongoing processes that is the digital revolution and the "digitalization" of universities.

From the point of view of the experts, it is "total digitalization" that is the main trend, which with a high probability will be manifested in the time horizon until 2035 and will have the strongest influence (in comparison with other processes) on the reality of higher education. Digitalization (the need for a large-scale use of digital technologies) will be a major challenge for universities - this challenge will manifest itself with a high probability and will have a significant impact on them. Other significant challenges are competition (with global universities and consortia) and internationalization (the need to teach in English, international accreditation of programs, etc.), as well as the massification of higher education but only for Russia.

At the same time, according to the experts, the proliferation of digital technologies is not among the most significant sources of risk, in other words, sources of "critical situations" for higher education. The possible degradation of school education ("weak" applicants who are difficult to be taught further) and the "raw material" socio-economic development scenario are seen as the sources of critical situations in the future.

Since the experts see the future as "digital", they, accordingly, consider investment in digital infrastructure (computer networks, computing power, software, electronic university system, digital educational environment) to be one of the priority areas for investing in the development of universities, and they expect "quick effects" or quick return on this investment.

However, according to experts, "PR and university promotion" rank the first among the actual priorities of the development of universities; they also estimated "Cooperation with the Ministry of Education and Science and federal agencies" very high; Digital infrastructure investment is in the third place. Thus, we can talk about a 
certain "strain" in university management: the tasks of PR and university promotion and interactions with the Ministry of Education "push aside" all the others, such as the task of digitalization (to a lesser extent) and the task of investing in activity, in cooperation (international and with business), in educational technologies, "new students" (to a greater extent), and especially in research studies and scientific schools, in new staff members.

Among the reforms of higher education that are ongoing and possible in the future in Russia, the "digitalization" of the educational process is considered both the leading and the most promising direction by experts and characterized by already manifested efficiency.

The results obtained in the article indicate the existing contradiction: on the one hand, the "digitalization" of reality around and within the university is the most significant trend and the most significant challenge; it is connected with the prospects of universities; on the other hand, in the current practice of "investment in the development" of universities, "digitalization" ranks $3^{\text {rd }}$. The priorities in this practice are: the struggle for the image and status of the university; building relationships with federal higher education authorities.

\section{References}

Akhtamov, E.A., Bezrukov, L.A., Bragin, V.I., Briukhanova, E.A., Voronov, Iu.P., Gergilev, D.N., Ershov, Iu.S., Efimov, V.S., Ionova, V.D., Kozyr’, V.V., Kolomyts, L.E., Kriukov, V.A., Lapteva, A.V., Makarov, I.A., Malov, V.Iu., Sarchenko, V.I., Tarasova, O.V., \& Shishatskii, N.G. (2017). Sibir' i Dal'nii Vostok v XXI veke: problemy $i$ perspektivy razvitiia: analiticheskii doklad [Siberia and the Far East in the 21 century: problems and prospects for development: analytical report]. Krasnoiarsk, Sibirskii federal'nyi universitet, 196 p.

Efimov, V.S., Lapteva, A.V., \& Rumiantsev, M.V. (2012a). Budushchee vysshei shkoly v Rossii - 2030: sotsial'no-ekonomicheskie konteksty i kriticheskie situatsii (po rezul'tatam Delfi-oprosa ekspertov) [The future of higher education in Russia - 2030: socio-economic contexts and critical situations (according to the results of the Delphi survey)], In Universitetskoe upravlenie: praktika $i$ analiz [University management: practice and analysis], 78(2), 24-37.

Efimov, V.S., Lapteva, A.V., \& Rumiantsev, M.V., Dadasheva, V.A., \& Efimov, A.V. (2012b). Budushchee vysshei shkoly v Rossii: ekspertnyi vzgliad. Forsait-issledovanie2030: analiticheskii doklad [The future of higher education in Russia: an expert 
view. Foresight study - 2030: analytical report]. Krasnoiarsk, Sibirskii federal'nyi universitet, 181 p. Available at: http://foresight.sfu-kras.ru/sites/foresight.sfu-kras.ru/ files/_Doklad_Vysshaya_shkola_-_2030_ekspertnyy_vzglyad_2012.pdf

Johnson, L., Adams Becker, S., Cummins, M., Estrada, V., Freeman, A. \& Hall, C. (2016). NMC Horizon Report: 2016 Higher Education Edition. Austin, Texas: The New Media Consortium, $50 \mathrm{p}$.

Neborskii, E.V. (2015). Obrazovanie budushchego: kliuchevye pedagogicheskie innovatsii i tendentsii $\mathrm{v}$ razvitii obrazovatel'noi sredy [Education of the future: key pedagogical innovations and trends in the development of the educational environment], In Internet-Zhurnal "Naukovedenie" [Internet-journal "Sociology of science"], 7(2). DOI: $10.15862 / 166 \mathrm{PVN} 215$

OECD (2016). Trends Shaping Education 2016. Paris, OECD Publishing, 115 p. Available at: http://www.oecd.org/education/trends-shaping-education-22187049.htm

Onlain-obuchenie: kak ono meniaet strukturu obrazovaniia i ekonomiku universiteta. Otkrytaia diskussiia Ia. I. Kuz'minov - M. Karnoi [Online learning: how it changes the structure of education and the economy of the university. Open discussion Ya.I. Kuzminov - M. Carnoy] (2015). In Voprosy obrazovaniia [Educational Studies Moscow], 3, 8-43.

Picciano, A. (2012). The Evolution of Big Data and Learning Analytics in American Higher Education. In Journal of Asynchronous Learning Networks, 16(3), 9-20.

Semenova, T.V., Vilkova, K.A., \& Shcheglova, I.A. (2018). Rynok massovykh otkrytykh onlain-kursov: perspektivy dlia Rossii [The market of massive open online courses: prospects for Russia]. In Educational Studies Moscow, 2, 173-197.

Siemens, G., Gašević, D., \& Dawson, Sh. (2015). Preparing for the digital university: a review of the history and current state of distance, blended, and online learning. Athabasca University, University of Edinburgh, University of Texas Arlington, University of South Australia, $230 \mathrm{p}$.

The World Bank (2016). World Development Report 2016: Digital Dividends. 330 p.

Trends in Higher Education Marketing, Recruitment, and Technology (2014). Hanover Research, 27 p.

Ustiuzhanina, E.V., Sigarev, A.V., \& Shein, R.A. (2017). Tsifrovaia revolutsiia i fundamental'nye izmeneniia $\mathrm{v}$ ekonomicheskikh otnosheniiakh [Digital revolution and fundamental changes in economic relations]. In Vestnik Cheliabinskogo gosudarstvennogo universiteta [Bulletin of Chelyabinsk State University], 406(10), Ekonomicheskie nauki [Economic sciences], 58, 15-25. 


\title{
Будущее университетов: приоритет цифровизации? (Экспертный взгляд)
}

\author{
В.С. Ефимов, А.В. Лаптева \\ Сибирский федеральный университет \\ Россия, 660041, Красноярск, пр. Свободньй, 79
}

Разворачиваюшаяся цุифровая револючия меняет окружаюшую университеть действительность и изменяет сами университеть. Цель исследования, представленного в статье, осветить ряд аспектов «цифровизации» университетов на основе экспертного знания. В качестве метода исследования использован масштабный опрос экспертов (1481 эксперт из 65 университетов России). Задача опроса - выявить, какое место занимает «циифровизация» среди других масштабных изменений; какое место занимает «цифровой вызов» среди других, актуальных для современного университета, вызовов; как данный вызов должен повлиять на приоритеть управления развитием университета; в какой мере реальные приоритеты управления российскими университетами отражают значимость «цицрового вызова».

Опрос показывает, что экспертное сообщество считает «тотальную ичифровизацию» ведущим трендом изменений экономики и общества. Главным вызовом для высшей школье в период до 2035 г. будет «цуифровизация» - необходимость масштабного использования иифровых технологий в образовании и в управлении университетом. При этом эксперты полагают, что «критические ситуации» для высшей школь в будущем могут возникнуть в результате возможной «деградации школьного образования» $и$ развития страны по "сырьевому» сценарию. Ускоренное технологическое развитие экономики и общества на основе циффровых технологий не станет значимым источником возможных критических ситуачий для высшей школы в будущем. В системе приоритетов развития инвестиции в ицифровую инфраструктуру должны занимать значимое место, причем можно ожидать «быстрые эффектыl» этих инвестиций.

Однако среди фактических приоритетов развития университетов на первых позиииях, по мнению экспертов, находятся «PR и продвижение университета» и «сотрудничество с Минобрнауки и федеральными агентствами»; инвестиции в иифровую инфраструктуру занимают третью позицию. Можно говорить об определенной «деформации» в управлении развитием университетов - главным трендом изменений, и вызовом для университетов является «цифровизация», которая в практике управления занимает среди приоритетов лишь третье место. Еще более низок фактический приоритет следующих направлений инвестиций в мотиващию преподавателей и студентов («инвестиции в активность»), международное сотрудничество, сотрудничество с бизнесом, развитие образовательных технологий, привлечение «новых студентов», привлечение «новых кадров», развертывание поисковых исследований, поддержку научных икол.

Ключевые слова: университеты, реформы высшей школь, циифровая револючия, иифровые технологии, приоритеты развития, инвестициии в развитие.

Исследование выполнено при поддержке краевого государственного автономного учреждения «Красноярский краевой фонд поддержки научной и научно-технической деятельности» в рамках реализачии проекта: "Перспективы формирования ичифровой экономики в Красноярском крае: приоритетные направления, технологии, кадры».

Научная специальность: 08.00.00 - экономические науки. 